\title{
What is the major public health problem: the morbid obesity or the bariatric surgery in the unified health system? (Part II)
}

\author{
Qual o maior problema de saúde pública: a obesidade mórbida ou a cirurgia \\ bariátrica no Sistema Único de Saúde (SUS)? (Parte II)
}

Fernando de Barros, TCBC-RJ

$T^{T}$ here are scientific and political mobilizations worldwide that have the fight against morbid obesity (MO) as main objective. In February 2011, several ministers of health of the Americas participated in the High-Level Regional Consultation of the Americas Against Chronic Noncommunicable Diseases (ECNT), and signed a proposal with public health goals and guidelines against $\mathrm{MO}^{1}$. Europe already considered this epidemic one of the biggest challenges in public health².

In 2013, there were 72,000 operations to treat $\mathrm{MO}$ in Brazil, and in 2014, more than 80,000 operations, following the US, in which 140,000 operations were carried out $^{3}$. Unfortunately, just over $10 \%$ of these operations in our country were performed in public hospitals. We are even more concerned when we see that much of obese patients (75\%) who need this operation can only be treated by the Unified Health System (SUS) and not by the health insurance one $e^{4}$. We then have three quarters of a population "allocated" in a system which performs one tenth of bariatric operations in the country.

The cost of the problem, in 2011, for the SUS was $R \$ 487.98$ million, representing $1.9 \%$ of spending on health care of medium and high complexity in the country 5 . Interestingly, spending on bariatric surgery itself were only $R \$ 31,5$ million, which may reflect an insufficient number of operations to the size of the problem. According to Zilberstein et al., the endless queues waiting for an operation on SUS reached 2.9 years in 2006, causing a mortality during the waiting period of $0.6^{6}$. Based on this work, and considering a linear growth of obesity of $0.024 \%$ a year ${ }^{7}$, plus the finding in 2010 by IBGE, of the MO epidemic, we have enough reasons to understand why currently the waiting list in the SUS has a mortality rate equal to or greater than the operation itself, around $1 \%{ }^{8}$.

Bariatric surgery in SUS was regulated by Decree No 196 of 29 February 2000, and initially established 22 reference centers in the country ${ }^{9}$. However, this ordinance certainly did not contemplate the events of the years that followed and ended up scaling one reference service in bariatric surgery for every four million people. In 2007, a new ordinance was published ${ }^{10}$, establishing guidelines for health care, with a view to preventing obesity and care to the obese, to be implemented in all federal units, respecting

1. Pesquisa Clínica, Fundação Oswaldo Cruz. the competencies of the three levels of management. Six years later, through Ordinance on 425 of 19 March 2013, the Ministry of Health determined, among other things, the human resources and infrastructure for the adequacy and registration of the "High Complexity Center for Patients with Obesity"11.

Brazil has now 78 units authorized by the Ministry of Health $(\mathrm{MOH})$ in 20 different states ${ }^{12}$. Despite various guidelines and imposed bureaucratic regulations, the system offers little or no financial or training encouragement to the staff. The result of this mismatch is that 12 states in 2011, did not perform the 96 operations/year required as a prerequisite to remain qualified as reference centers. We have the impression, at this time, of a system biased towards a vicious cycle, where the productivity demand is made first and the initiative must be local; then the support resources arrive, which, in turn, does not cover $100 \%$ of the real needs. In 2011, 5,357 operations were performed in the SUS and, in 2012, slightly less than 6000. In the face of so many difficulties of everyday life of a Brazilian public hospital, plus the inefficient management model across the country to care for the morbidly obese, currently tertiary centers not registered by the $\mathrm{MOH}$ are implementing new bariatric surgery programs independently, which may indicate that the number of operations performed in the SUS may be underestimated. Again, the system turns against itself. If there is a highly complex program being carried out, but without proper recognition by managing entities, there is failure in statistics, there is no extra local funds reimbursement, there is no incentive, no staff training, programs are not sustainable, rendering losses to the local manager. This culminates in forming another "island", isolated in the system with their own and endless queues of patients waiting for an operation.

There is, no doubt, urgency in reviewing some guidelines. Even after almost 20 years of consecration of the method in Brazil, laparoscopic surgery is not covered by SUS for bariatric surgery. Several studies have demonstrated the highest efficiency and the lowest complication rate for this method ${ }^{13,14}$. In addition, it has been shown that the higher initial cost of laparoscopic surgery is offset by the savings in spending on length of stay, complications and readmissions ${ }^{15}$. Sussenbach et al. questioned 32 bariatric surgeons as to how would each of their services be should there be incorporation by SUS of 
the laparoscopic method for the surgical treatment of $\mathrm{MO}^{12}$ and concluded that all respondents prefer the laparoscopic approach, believing that there would be more operations compared with laparotomy.

If there is a safer, less complication, preferably methods, preferred by the majority of surgeons and cheaper for public health, why not apply it? The cycle of a model of bureaucratic management not oriented to the up-to-date analysis of the population's needs repeats, confirming what for some is fact: SUS does not. But is it so? It is true that the SUS is currently undergoing a serious crisis. Since its creation in 1988, health in the country has become a universal right and duty of the state, becoming one of the largest public health systems in the world. Admittedly, who created the system did it with extreme perfection, but one detail was overlooked: exemplary management. After 27 years of its existence, the SUS is far from perfection. During this period we witnessed serious management failures and, according to press reports, misappropriation of health resources and hence scrapping of the services rendered to the population. If we make an analogy and observe the numerous decrees issued by the Ministry of Health for the care in the MO health-disease process, we can clearly see the gap between what is written and what is put into practice.

The approval of the Practice Area in Bariatric Surgery by the Federal Council of Medicine will expand the horizons of bariatric and metabolic surgery in Brazil, especially with regard to the formation of residents and to the continuing education of specialists in the field. In this moment of euphoria we have to think again about SUS. How will be the medical residency programs for surgeons interested in bariatric surgery? Will the SUS bariatric surgery reference centers be prepared to receive them? Will the residents be well-trained and ready to perform bariatric surgery in this current model? What will be the role of Surgical Societies in this training?

Certainly, major steps have been taken, but to consolidate them, we need to know how to advance in the political discussion, regulations, guidelines and undoubtedly in SUS management models. As we said, we live in a time of great changes in the world's epidemiological profile, and particularly in Brazil. Morbid obesity is among the serious health problems to be faced. Hopefully bariatric surgery in SUS - one of the important solutions to the problem - will not become a bigger problem than the disease itself due to its bureaucracy and inefficiency. Hopefully the first question answered here, "which is the largest public health problem: morbid obesity or bariatric surgery in SUS", will be quickly answered

\section{REFERENCE}

1. Castro C. Ministros da Saúde das Américas se comprometem a criar políticas públicas para reduzir a obesidade no continente. São Paulo: Associação Brasileira para o Estudo da Obesidade ABESO; 2011. Acessado 06 mar 2011. Disponível em: http://www. abeso.org.br/

2. Organização Pan-Americana da Saúde. Doenças crônicodegenerativas e obesidade: estratégia mundial sobre alimentação saudável, atividade física e saúde. Brasília: Organização PanAmericana da Saúde; 2003.

3. Ramos AC. Brazil looking for completing his space in bariatric surgery. $A B C D$, arq bras cir dig. 2014;27(Suppl 1):1.

4. Fundação Instituto Brasileiro de Geografia e Estatística. Pesquisa Nacional por Amostra de Domicílios - PNAD/BrasiL. 1998. Análise de Resultados. Acessado em 23 jul 2010. Disponível em: http:// www.ibge.gov.br/home/estatistica/populacao/ trabalhoerendimento/pnad98/saude/analise.shtm

5. Oliveira ML. Estimativa dos custos da obesidade para o Sistema Único de Saúde do Brasil [tese]. Brasília, DF: Universidade de Brasília, Faculdade de Ciências da Saúde; 2013.

6. Zilberstein B, Halpern A, Monteiro SM, Lunardi A, Campoleone S, Souza AC, et al. Waiting time for bariatric surgery in a public hospital in Brazil: a problem to be solved. Obes Surg. 2006:16:1023.

7. Instituto Brasileiro de Geografia e Estatística. Diretoria de Pesquisas. Pesquisa de Orçamentos Familiares 2008-2009 - POF. Rio de Janeiro:IBGE; 2011

8. Benotti P, Wood GC, Winegar DA, Petrick AT, Still $C D$, Argyropoulos $G$, et al. Risk factors associated with mortality after Roux-en-Y gastric bypass surgery. Ann Surg. 2014:259(1):123-30.

9. Ministério da Saúde. Portaria n 196, de 29 de fevereiro de 2000, Institui os critérios clínicos para a indicação de realização de gastroplastia como tratamento cirúrgico da obesidade mórbida no âmbito do Sistema Único de Saúde. Diário Oficial da União 01 mar 2000

10. Ministério da Saúde. Portaria n 1569, de 28 de junho de 2007 institui diretrizes para a atenção à saúde, com vistas à prevenção da obesidade e assistência ao portador de obesidade, a serem implantadas em todas as unidades federadas, respeitadas as competências das três esferas de gestão. Diário Oficial da União 02 jul 2007.

11. Ministério da Saúde. Portaria n 425, de 19 de março de 2013 Estabelece regulamento técnico, normas e critérios para o Serviço de Assistência de Alta Complexidade ao Indivíduo com Obesidade. Diário Oficial da União 2013. Diário Oficial da União 20 mar 2013.

12. Sussenbach S, Silva EN, Pufal MA, Rossoni C, Casagrande DS Padoin AV, et al. Implementing laparoscopy in Brazil's National Public Health System:the bariatric surgeons' point of view. $A B C D$, arq bras cir dig. 2014;27 (Suppl 1):39-42.

13. Tiwari MM, Reynoso JF, High R, Tsang AW, Oleynikov D. Safety, efficacy, and cost-effectiveness of commomlaparosocopic procedures. SurgEndosc. 2011;25(4):1127-35.

14. Reosch J, Mottillo S, Shimony A, Filion KB, Christou NV, Joseph L, et al. Safety of laparoscopic vs open bariatric surgery: a systematic review and meta-analysis. Arch Surg.2011;146(11):1314-22.

15. Nguyen NT, Goldman C, Rosenquist CJ, Arango A, Cole CJ, Lee SJ, et al. Laparoscopic versus open gastric bypass: a randomized study of outcomes, quality of life, and costs. Ann Surg. 2001;234(3):27989; discussion 289-91. 